\begin{tabular}{|c|l|}
\hline Title & Planktonic foraminiferal zonation in the Cretaceous Y ezo Group, Central Hokkaido, Japan \\
\hline Author(s) & $\begin{array}{l}\text { Nishi, Hiroshi; Takashima, Reishi; Hatsugai, Takay uki; Saito, T sunemasa; Moriya, Kazuy oshi; Ennyu, A tsuhito; Sakai, } \\
\text { Toshiaki }\end{array}$ \\
\hline Citation & $\begin{array}{l}\text { Journal of A sian Earth Sciences, 21(8), 867-886 } \\
\text { https://doi.org/10.1016/S1367-9120(02)00138-4 }\end{array}$ \\
\hline Issue Date & 2003-06 \\
\hline Doc URL & http://hdl.handle.net/2115/17185 \\
\hline Type & article (author version) \\
\hline File Information & JAES21-8.pdf \\
\hline
\end{tabular}

Instructions for use 


\title{
Planktonic foraminiferal zonation in the Cretaceous Yezo Group, Central Hokkaido, Japan
}

Hiroshi Nishi ${ }^{a}$, Reishi Takashima ${ }^{a}$, Takayuki Hatsugai ${ }^{b}$, Tsunemasa Saito ${ }^{c}$, Kazuyoshi Moriya $^{\mathrm{d}}$, Atsuhito Ennyu ${ }^{\mathrm{e}}$ and Toshiaki Sakai ${ }^{\mathrm{f}}$

aDepartment of Earth Science, Graduate School of Social and Cultural Studies, Kyushu University, 4-2-1, Ropponmatsu, Chuo-Ku, Fukuoka, 810-8560, Japan, E-mail: hnishi@rc.kyushu-u.ac.jp.

${ }^{b}$ GeoPlannig Limited Responsibility Company, Ichinazaka, Aza Higashiura 78-1, Izumi-Ku, Sendai, 981-3117, Japan.

'Institute of Geology and Paleontology, Tohoku University, Aoba, Aramaki, Sendai, 980-8578, Japan.

${ }^{\mathrm{d} D e p a r t m e n t}$ of Earth and Planetary Science, Graduate School of Science, the University of Tokyo, 7-3-1 Hongo, Bunkyo-ku, Tokyo, 113-0033, Japan.

eDepartment of Geosciences, The Pennsylvania State University, 437 Deike Building, University Park, PA 16802, USA.

${ }^{\mathrm{f}}$ Division of Geology, Nipponkoei Corporation, JA Saitama Building 9F, Dotemachi 1-2, Oomiya City, Saitama, 330-0801, Japan

\begin{abstract}
The mudstone of the Yezo Group exposed in Central Hokkaido yields abundant microfossils of calcareous nannofossils, foraminifers, radiolarians and dinoflagellates. Benthic foraminifers consisting of both agglutinated and calcareous species occur abundantly and consistently throughout the sequence, while specimens of planktonic foraminifers are generally fewer than benthics in all samples. We recognized the following 13 planktonic foraminiferal zones
\end{abstract}


assigned to the late Aptian to early Campanian in the Oyubari and Haboro-Kotanbetsu areas; 1) Globigerinelloides spp., 2) Ticinella primula, 3) Biticinella breggiensis, 4) Rotalipora subticinensis-Rotalipora ticinensis, 5) Rotalipora appenninica, 6) Rotalipora globotruncanoides, 7) Rotalipora cushmani, 8) Whiteinella archaeocretacea, 9) Helvetoglobotruncana helvetica, 10) Marginotruncana pseudolinneiana, 11) Marginotruncana sinuosa, 12) Contusotruncana fornicata, 13) Globotruncana arca.

The Globigerinelloides spp. to $H$. helvetica zones (late Aptian to early Turonian) can be correlated with standard zones in the Tethyan regions, whereas the assemblages from the M. pseudolinneiana to G. arca zones lack tropical zonal markers of Dicarinella concavata, D. asymetrica and Globotruncanita elevata in many studied sections. The scarcity or lack of tropical zonal species during the late Turonian to early Campanian suggests that the Oyubari and Haboro-Kotanbetsu regions in Hokkaido were located in the Transitional to Boreal biogeographical provinces. 


\section{Introduction}

Many lines of evidence suggest that an equable climate expanded from the low- to high-latitudes during the middle to late Cretaceous interval when the globally averaged surface temperatures were $6-14^{\circ} \mathrm{C}$ higher than at present (Barron, 1983), $\mathrm{pCO}_{2}$ contained two to ten times the present-day values (Berner, 1994), and no permanent ice caps existed in both polar regions (Frakes, 1979). Extreme high-latitude warmth during the mid-Cretaceous has recently been supported by oxygen isotope paleotemperature estimates (Huber et al., 1995, Clark and Jenkins, 1999), paleobotanical evidence (Spicer and Parrish, 1986; Herman and Spicer, 1996; Parrish et al., 1998) and the occurrence of a cold-blooded reptile at northern high latitudes (Tarduno et al., 1998). The differences between the low- and high-latitude surface-water paleotemperatures are estimated at about $14^{\circ} \mathrm{C}$ during the late Albian and late Maastrichtian, but the latitudinal temperature gradient during the Coniacian-Santonian interval was only $0-4^{\circ} \mathrm{C}$ (Huber et al., 1995; MacLeod et al., 2000).

The biogeographic provincialization of planktonic foraminifers as well as other marine invertebrate fossils such as ammonites, inoceramids and rudists probably formed during the mid-Cretaceous time (Douglas, 1969; Douglas and Rankin, 1969; Sliter, 1972; Huber, 1992a; 1992b; Johnson et al., 1996). Four realms of foraminiferal bioprovinces existed in the Cretaceous: Tethyan (Tropical-Subtropical), Boreal in the Northern Hemisphere (cool Temperate), Austral in the Southern Hemsphere (equivalent to the Boreal Realm), and Transition (warm Temperate), (Caron, 1985; Malmgren, 1991; Huber, 1992a; 1992b; Gasinski, 1997).

The standard biostratigraphic zonations of planktonic foraminifers are generally established in the tropical-subtropical Tethyan realm (Caron, 1985; Sliter, 1989; Hardenbol et al., 1998;). The Tethyan zonal scheme cannot be applied for faunal assemblages in the Boreal and Austral realms (Douglas and Rankin, 1969; Huber, 1992a). The Transitional realm shows intermediate characteristics between the Tethys and the Boreal realms (Douglas, 1969; Hart et al., 1989). This transitional bioprovince is significant for the latitudinal 
correlation between assemblages of both the Tethyan and Boreal (Austral) realms. Furthermore, the occurrence of Tethyan taxa included in the Transitional Realm reflects the change of global climate and paleoceanography that controlled the latitudinal movement of tropical-subtropical faunas.

The Yezo Group is distributed widely in Central Hokkaido, northern Japan and consists of thick Cretaceous sequences containing abundant microfossils (planktonic and benthic foraminifers, radiolarians and dinoflagelates), associated with macrofossils of ammonites and inoceramids. Central Hokkaido is thought to have been located in the mid-latitudes (about $40-50^{\circ} \mathrm{N}$ ) during the Cretaceous (Fig. 1). However, the fossil assemblages collected from the Yezo Group contain some typical Tethyan faunas, suggesting the Transition Realm. Probably, the westland warm current (precursor to the present-day Kuroshio Current) frequently reached the area where the Yezo Group had been deposited.

The purpose of this paper is to propose a new planktonic foraminiferal zonal scheme, and to reveal the biotic characteristics of each zone defined here, compared with the Tethyan zonations. We also discuss the Transitional bioprovincial features of the planktonic foraminiferal assemblages in the Yezo Group, and finally suggest climatic implications during the Cretaceous interval.

\section{Material and methods}

Systematic sampling of hard mudstone and siltstone samples was made along 14 selected sections in the Kotanbetsu area, and 21 sections in the Oyubari area (Fig. 2). More than 1000 samples were collected. All samples (each weighing $1 \mathrm{~kg}$ ) were first treated with sodium sulfate $\left(\mathrm{Na}_{2} \mathrm{SO}_{4}\right)$, and later with tetraphenylborate (NaTPB). The disaggregated samples were washed over a $63 \mu \mathrm{m}$ sieve. All planktonic specimens were picked and mounted to the assemblage slides.

In this study, abundance of planktonic foraminiferal specimens collected from the samples was estimated as follows: a total of 1-2 specimens are rare; 3-5 specimens are few; 6-9 are common; and $>10$ indicates that the specimens are abundant in this sample. The washed residues contain abundant 
specimens through the Turonian to Campanian interval, whereas the specimens of the Aptian to Cenomanian are frequently few to rare. The benthic foraminifers are more common than planktonic specimens in all samples.

\section{Lithostratigraphy of the investigated area}

The Cretaceous deposits are widely exposed in the central part of Hokkaido, Japan, extending from the Kanayama-Urakawa area in the southern part of Hokkaido, to the Soya-Teshinakagawa area in North Hokkaido (Fig. 2), and finally northward to the Sakhalin-Kamchatka area. The total distance of the distribution is about $2400 \mathrm{~km}$, and the total thickness of siliciclastic sediments is over 5000-6000 m (Hirano et al., 1992; Kiminami et al., 1992). These sediments are accumulated in Cretaceous forearc regions along the subduction zone of the northwestern Asian Continent.

The Yezo Group conformably overlies the Jurassic-Cretaceous Sorachi Group that consists mainly of basaltic lavas and their clastics, siliceous tuffs, limestone, and siliciclastic sandstone and mudstone. Although the neritic (shelf) to coastal facies are known as the Albian to Turonian Mikasa Formation in the western part of Hokkaido (Ando, 1990a; 1990b), the Yezo Group is dominated by deep-marine sediments comprising thick mudstone, turbidite sandstones and their alternating beds, interbedded with olistostrome beds and acidic volcanoclastic sediments. These rocks are distributed separately in three main areas; the Oyubari, Haboro-Kotanbetsu and Soya-Teshinakagawa, respectively, from south to north (Fig. 2). In this paper, we selected the Oyubari and Haboro-Kotanbetsu areas in which to study the lithostratigraphy and biostratigraphy of planktonic foraminifers.

The sequence of the Oyubari area crops out in the southernmost part of the investigation area, and is divided into five formations: the Shupparogawa, Maruyama, Hikagenosawa, Takinosawa and Kashima Formations in ascending order (Motoyama et al., 1991; Takashima et al., 1997; Fig. 3 in this paper). The Shuparogawa Formation is composed of sandstone-dominated turbidite beds interbedded with the olistostrome or slump beds that sometimes contain reefal limestone blocks. The Maruyama Formation is characterized by debris flows of 
acidic-volcanoclastic rocks, sandstone, and hard siliceous tuff beds. The olistostromes and the Maruyama Formation are recognized as excellent lithostratigraphic markers, and are assigned to the uppermost Aptian and the middle Albian, respectively. They are traceable from the Oyubari to Soya-Teshionakagawa areas in the Central Hokkaido. The dominant lithology of the Takinosawa Formation is alternating beds of sandstone and mudstone, while that of the Hikagenosawa Formation is laminated mudstone, accompanied with tuff beds and thin-bedded sandstone turbidites (Fig. 3). The uppermost Kashima Formation comprises massive mudstone yielding abundant microfossils. The paleodepth of mudstone in the Yezo Group is inferred to be the upper-bathyal zone, $300-600 \mathrm{~m}$ during the Cenomanian-Turonian and 150-600m during the Coniacian-Campanian based on the benthic foraminiferal assemblages (Kaiho et al., 1993).

In the Kotanbetsu area, the Cretaceous sequence consists of five formations: the Takimibashi, Tenkaritoge, Shirochi, Middle Haborogawa, and Upper Haborogawa Formations from bottom to top (Wani and Hirano, 2000; Fig. 3 in this paper). The rocks are classified lithologically into two units. The Takimibashi, Shirochi and Upper Haborogawa Formations belong to a turbidite unit, interbedded with slump beds and thick sandstones. The Tenkaritoge and Middle Haborogawa Formations are massive mudstone units, intercalated with turbidite sandstones and thin tuff beds. The two lithological units repeat stratigraphically and alternate throughout the sequence (Fig. 3). The Shirochi Formation is correlated with the Takinosawa Formation in the Oyubari area.

In the Haboro area, located in the northern part of the study area, the Cretaceous strata are composed of the turbiditic Shirochi Formation, the massive mudstone Lower and Middle Haborogawa Formations, and again the turbiditc Upper Haborogawa Formation in ascending order (Toshimitsu, 1988; Fig. 3 in this paper). This distinct cyclic sedimentation of turbidite-mudstone-turbidite is the same as the pattern observed in the Kotanbetsu area.

The lower half of the sequences exposed in the Haboro-Kotanbetsu areas are lithostratigraphically similar to the rocks in the Oyubari area, suggesting a continuous sedimentary basin. However, the upper half of the two 
areas represents the northward-coarsening sequences with the thick mudstone unit in the southern Oyubari area grading into the turbidite in the northern Habaro-Kotanbetsu area (Fig. 3).

\section{Biostratigraphic zonation during the Cretaceous}

The development of the present international biostratigraphic zonal schemes using macrofossils and microfossils provides the essential biochronologic framework for the detailed correlations of low-to-high latitudes or Tethyan-to-Boreal regions. These traditional methods are supported by new methods of chemostratigraphy and sequence stratigraphy. For example, the positive excursions of carbon isotope $\partial^{13} \mathrm{C}$ during the mid-Cretaceous are used as remarkable event markers of five stratigraphic levels of the Oceanic Anoxic Events (OAEs) 1a (early Aptian), 1b (earliest Albian), 1c (early late Albian), 1d (late Albian) and 2 (latest Cenomanian)(e.g. Erbacher et al., 1996; Erbacher and Thurow, 1997).

On the other hand, Caron (1985) and Sliter (1989) proposed 28 and 31 zones of planktonic foraminifers, respectively, from the Hauterivian to Maastrichtian (132-65Ma), a mean stratigraphic resolution of 2.2-2.5 m.y. per zone (Fig. 4). Recently, Hardenbol et al. (1998) compiled the Mesozoic sequence stratigraphy and biostratigraphy of European Basins, calibrated the age of zonal boundary using a time scale of Gradstein et al. (1995). Some 16 zones of planktonic foraminifers in the early Cretaceous (Berriasian-Albian) and 15 of the late Cretaceous (Cenomanian-Maastrichtian) are defined in European Basins (Fig. 4). The resolution of this biostratigraphic scheme is about $2.8 \mathrm{~m}$.y. per zone for the Lower Cretaceous and 2.3 m.y. per zone for the Upper Cretaceous.

Huber (1992a) presented seven zones in the southern high-latitude (austral) region from the Cenomanian to Maastrichtian. This scheme is based on the deep-sea sites drilled poleward of $50^{\circ} \mathrm{S}$ paleolatitude. Douglas (1969) and Takayanagi (1965) proposed other zonal schemes in the middle-latitude regions around $40^{\circ} \mathrm{N}$ in the Great Valley Cretaceous sequence, northern California. In southern and eastern England, including the southern North Sea Basin, Hart et al. (1989) recognized 17 zones through the Cenomanian-Maastrichtian interval. 
These high- and middle-latitude zonal schemes are characterized by a low total diversity, abundant cosmopolitan forms, and the restricted occurrence of the tropical-subtropical Tethyan species, which results in the difficulty of the latitudinal correlations between the Tethys and Boreal (Austral) realms.

\section{Biostratigraphy of planktonic foraminifers in the Yezo Group}

Maiya and Takayanagi (1977) first proposed seven planktonic and six benthic foraminiferal zones ranging from the Barremian to Maastrichtian in Central Hokkaido, Japan. Later, Maiya (1985) revised these zones into a total of 10 planktonic and 10 benthic foraminiferal zones. However, the detailed stratigraphic distribution and taxonomic description of each species have not been reported in these studies.

We selected several sections distributed in the Oyubari and Haboro-Kotanbetsu areas to reveal the stratigraphic distribution of planktonic foraminifers and their faunal assemblages (Figs 5, 6, 7 \& 8). Takashima et al. (1997) reported a preliminary result from the Oyubari area, and revealed the necessity to redefine the previous scheme of Maiya (1985). Some 13 zones are proposed here as follows in stratigraphic order (Fig. 4).

(1) Globigernelloides spp. Assemblage Zone

Definition: Biostratigraphic interval from the FAD (First appearance datum) of Leupoldina cabri to the simultaneous FAD of Ticinella primula and Favusella washitensis. This zone corresponds to the joint interval from the "Globigerina" kugleri zone to the Globigerinelloides ferreolensis zone of Takashima et al. (1997).

Remarks: Planktonic specimens are rare and scattered in this interval. The assemblages consist mainly of small species with low- trochospiral to planispiral shapes, belonging to the genera of Globigerinelloides and Hedbergella. The most common species are Hedbergella delrioensis, H. planispira and Hedbergella trocoidea, associated with rare Globigerinelloides duboisi and a few trochospiral specimens of Gorbachikella kugleri (Fig. 5). The upper part of this zone also contains Globigerinelloides aptiense, G. barri and G. ferreolensis. 
Age and Correlation: Hardenbol et al. (1998) used Leupoldina cabri, Globigerinelloides algerianus, Planomalina cheniourensis and Ticinella bejaouaensis as the Aptian zonal markers (Fig. 4). However, the latter three species have not been found in the areas under investigation. The Shuparogawa Formation in the Oyubari area yields rare Leupoldina cabri in the lower part, and contains several planispiral forms of Globigerinelloides aptiense, G. barri and G. ferreolensis together just below the olistostrome beds of the Shuparogawa Formation, at about 300m above the LAD (Last appearance datum) of L. cabri (Fig. 5).

According to Longoria (1974), G. barri first appears at the base of the G. algerianus zone, and disappears at the top of the Hedbergella gorbachikae zone. Consequently, the Globigernelloides spp. zone corresponds to the joint interval from the G. ferreolensis zone to the Hedbergella planispira zone of Hardenbol et al. (1998) or from KS8 to KS12 of Sliter (1989)(Fig. 4). However, further work is needed to arrive at a reliable zonation because of the sporadic occurrence of the few specimens known throughout this interval. The age of this zone is thought to be the late Aptian.

(2) Ticinella primula Interval Zone

Definition: Biostratigraphic interval from the simultaneous FAD of Ticinella primula and Favusella washitensis, to the FAD of Biticinella breggiensis.

Remarks: This zone is characterized by the constant occurrence of ticinellids (Ticinella primula and T. roberti) and favusellids (Favusella washitensis) (Fig. 5). The faunas of this zone are still dominated by Hedbergella planispira and $H$. delrioensis, associated with rare H. simplex.

Age and Correlation: The latest Aptian to early Albian faunas of planktonic foraminifers contain well-diversified ticinellids. T. roberti and T. raynaudi also appeared during the early to middle Albian (Caron, 1985). Furthermore, the FADs of T. primula and B. breggiensis represent the zonal boundary of this zone are excellent bioevents of the middle Albian (Caron, 1985; Sliter, 1989). The T. primula zone in this paper can be correlated with the joined interval from the $T$. 
primula zone to the lower part of the Ticinella praeticinensis zone of Hardenbol et al. (1998), or with the T. primula zone of Caron (1985) and KS13 of Sliter (1989) (Fig. 4). The duration of this zone is considered to be a long span, about $6.09 \mathrm{~m}$. yr. (108.21-102.12Ma), and is assigned to the late early to middle Albian.

(3) Biticinella breggiensis Interval Zone

Definition: Biostratigraphic interval from the FAD of Biticinella breggiensis to the FAD of Rotalipora subticinensis.

Remarks: Few specimens of the nominate taxon occur few in the lower part of this interval, and they are rare in the upper interval. Common species are Ticinella roberti and $T$. primula, together with a few specimens of Favusella washitensis and T. raynaudi (Fig. 5). Hedbergella delrioensis and H. planispira are still common throughout this interval. Globigerinelloides bentonensis is rare.

Age and Correlation: This zone corresponds to the upper part of the $T$. praeticinensis zone of Hardenbol et al. (1998), the Biticinella breggiensis zone of Caron (1985) and KS14a of Sliter (1989). The age of this zone is the late middle Albian.

(4) Rotalipora subticinensis-Rotalipora ticinensis Partial Range Zone

Definition: Biostratigraphic interval from the FAD of Rotalipora subticinensis to the simultaneous FAD of Rotalipora appenninica and Praeglobotruncana stephani.

Remarks: The assemblages in the upper part of this interval are characterized by scattered, very scarce specimens. Rotalipora subticinensis is very rare in the Yezo Group. We have as yet found no specimen of Rotalipora ticinensis in the study area. The faunas in this interval included rare specimens of Ticinella roberti, T. primula and T. raynaudi (Fig. 5). Other characteristic species are Globigerinelloides bentonensis, Hedbergella planispira, H. simplex and Favusella washitensis.

Age and Correlation: The R. subticinensis and $R$. ticinensis zones are proposed as 
the interval zones and subzones defined by the successive three FADs of $R$. subticinensis, R. ticinensis and Rotalipora appenninica (Leckie, 1984; Caron, 1985; Sliter, 1989; Hardenbol et al., 1998). The Rotalipora subticinensis-Rotalipora ticinensis zone defined here is correlated with the joint interval from the $R$. subticinensis to R. ticinensis zone of Hardenbol et al. (1998) and Caron (1985), or from KS14a to KS15 of Sliter (1989)(Fig. 4). The age of this zone is the late Albian.

(5) Rotalipora appenninica Interval Zone

Definition: Biostratigraphic interval from the simultaneous FAD of Rotalipora appenninica and Praeglobotruncana stephani, to the FAD of Rotalipora globotruncanoides (=Rotalipora brotzeni).

Remarks: Rotalipora appenninica and R. gandolfii first occurred at the base of this interval, together with Praeglobotruncana stephani and P. delrioensis in the Yezo Group (Fig. 5). These species are few to common in this interval. The Ticinella group is very rare, and disappeared within this interval. Other common species are Favusella washitensis, Globigerinelloides bentonensis and Hedbergella delrioensis. H. simplex specimens are few to rare.

Age and Correlation: This zone corresponds to the $R$. appenninica zone of Hardenbol et al. (1998) and Caron (1985), or KS16 of Sliter (1989)(Fig. 4). The age of this zone is the latest Albian.

(6) Rotalipora globotruncanoides Interval Zone

Definition: Biostratigraphic interval from the FAD of Rotalipora globotruncanoides to the simultaneous FAD of Rotalipora greenhornensis and R. cushmani. This interval is identical to the lower part of the $R$. brotzeni zone of Takashima et al. (1997). We changed the name of the nominate taxon in this interval because Rotalipora brotzeni is a junior synonym of $R$. globotruncanoides (Robaszynski and Caron, 1995).

Remarks: The assemblages of this interval contain a few persistent specimens of 
$R$. appenninica, R. globotruncanoides and $R$. gandolfii. Praeglobotruncana delrioensis and P. stephani are common throughout this interval (Figs. 5 \& 6). Other common species are Globigerinelloides bentonensis, Hedbergella delrioensis and $H$. simplex.

Age and Correlation: The FADs of $R$. globotruncanoides, R. reicheli, and $R$. cushmani are used as excellent bioevents in the Cenomanian tropical-subtropical zonal schemes (Leckie, 1984; Caron, 1985; Sliter, 1989; Hardenbol et al., 1998). The Albian/Cenomanian boundary, dated at $98.9 \mathrm{Ma}$, is placed just above the FAD of R. globotruncanoides (Fig. 4).

R. reicheli has not been found in the study area, while $R$. greenhornensis and R. cushmani occurred in the studied sequences (Figs. 5 \& 6). However, abundances of the latter two species are rare to few. This zone is correlated with the joint interval from the $R$. globotruncanoides (=brozeni) zone to the $R$. reicheli zone of Caron (1985) and Hardenbol et al. (1998), and from KS17 to KS18 of Sliter (1989)(Fig. 4). The age of this zone is the early to middle Cenomanian.

(7) Rotalipora cushmani Interval Zone

Definition: Biostratigraphic interval from the simultaneous FAD of Rotalipora greenhornensis and R. cushmani to the LAD of Rotalipora spp.

Remarks: The mudstone in this interval yields rare to few specimens of $R$. appenninica, R. cushmani, R. deeckei, R. globotruncanoides, $R$. greenhornensis, and $R$. montsalvensis (Figs. 5, 6 \& 7). The common species are P. stephani, P. delrioensis and $P$. gibba. Whiteinella baltica appears first within this zone, and its occurrence is common to abundant throughout the sequences. Hedbergella delrioensis, $H$. simplex and G. ultramicrus are consistently present, but are few in abundance.

Age and Correlation: The Rotalipora cushmani Zone is widely recognized as the interval zone between the LADs of $R$. reicheli and $R$. cushmani in the tropical-subtropical areas (Leckie, 1984; Caron, 1985; Sliter, 1989; Hardenbol et al., 1998). Rotalipora cushmani disappears at 93.9Ma, just above the LADs of $R$. globotruncanoides, $R$. appenninica and $R$. reicheli that is dated at $94.71 \mathrm{Ma}$ 
(Hardenbol et al., 1998).

Rotalipora cushmani is vary scarce or absent, and disappears prior to other Rotalipora species in some studied sequences (Figs. 5, 6 \& 7). Hence, we used tentatively the LAD of Rotalipora species (Rotalipora appenninica, $R$. globotruncanoides, R. greenhornensis and R. montsalvensis) as the top boundary markers of this zone. In the Shirokin River located in the southern region far from the study area, $R$. cushmani disappeared together with $R$. greenhornensis just below the Cenomanian/Turonian boundary (Hasegawa, 1999).

More detail sampling than has been applied to this study is necessary to determine the reliable datum of the last rotaliporids in Central Hokkaido. This zone is identical with the R. cushmani zone of Caron (1985) and Hardenbol et al. (1998) or KS19 of Sliter (1989)(Fig. 4). The age of this zone is the late Cenomanian.

(8) Whiteinella archeocretacea Interval Zone

Definition: Biostratigraphic interval between the LAD of Rotalipora spp. and the FAD of Helvetoglobotruncana helvetica.

Remarks: This zone is characterized by abundant to common occurrences of weakly keeled- to non-keel forms of P. stephani, P. gibba, W. baltica, W. inornata, and $W$. archaeocretacea. Hedbergella delrioensis is common throughout this interval (Figs. 5, 6 \& 7). Globigerinelloides ultramicrus rapidly increased in abundance in the uppermost part of this interval. Whiteinella praehelvetica first appears close to the basal part of this interval (Fig. 5).

Age and Correlation: This zone can be correlated with the Whiteinella archaeocretacea zone defined as the interval zone from the LAD of Rotalipora cushmani to the FAD of H. helvetica in the standard zonations (Caron, 1985; Sliter, 1989; Hardenbol et al., 1998). The positive excursion of carbon isotope ratios $\left(\partial^{13} \mathrm{C}\right)$ related with an Ocean Anoxic Event (OAE) was observed within the $W$. archaeocretacea zone in marine carbonate rocks used as the stratigraphic marker of the Cenomanian/Turonian boundary (e. g. Scholle and Arthur, 1980; Arthur et al., 1987; Jenkyns et al., 1994). 
In Hokkaido, the positive excursion of carbon isotopes measured from terrestrial organic matter was reported between the LAD of R. cushmani and the FAD of $H$. helvetica in the Oyubari and Kotanbetsu regions (Hasegawa and Saito, 1993; Hasegawa and Hatsugai, 2000). Hasegawa (1995) also indicated that sandstone beds containing abundant radiolarian fossils occur just above this excursion level. Similar radiolarian beds within the $W$. archaeocretacea zone were found in many sections of the Oyubari and Haboro-Kotanbetsu areas, and are used as key beds close to the Cenomanian/Turonian boundary event (Figs. 5 \& 7). The age of this zone is assigned to the latest Cenomanian to early Turonian.

(9) Helvetoglobotruncana helvetica Total Range Zone

Definition: Biostratigraphic interval represented by the total range of the nominate taxon, Helvetoglobotruncana helvetica.

Remarks: The assemblages of this zone contain abundant non-keeled species of $W$. baltica, W. inornata and $W$. archaeocretacea. The single-keeled forms of Helvetoglobotruncana helvetica and $W$. praehelvetica are few in abundance, while the double-keeled group of Dicarinella canaliculata, D. hagni, Marginotruncana pseudolinneiana and $M$. marginata are consistently common, but more rarely they are abundant in this interval (Figs. 7, 8 \& 9). Globigerinelloides ultramicrus and Hedbergella delrioensis are present throughout this interval.

Age and Correlation: The Helvetoglobotruncana helvetica total-range zone is widely recognized in the Tethyan standard zonations (Fig. 4). The age of this zone is assigned to the early to middle Turonian.

(10) Marginotruncana pseudolinneiana Interval Zone

Definition: Biostratigraphic interval between the LAD of Helvetoglobotruncana helvetica and the FAD of Marginotruncana sinuosa.

Remarks: The non-keeled forms of $W$. archaeocretacea, $W$. baltica and $W$. inornata are still common to abundant in this interval, while the double-keel forms (Dicarinella canaliculata, D. hagni, D. imbricata, M. pseudolinneiana and $M$. 
marginata) are few to rare. Dicarinella concavata is also scattered and very rare (Figs. 7 \& 8). Globigerinelloides ultramicrus, Hedbergella delrioensis and Heterohelix reussi have few occurrences throughout this interval (Fig. 9).

Age and Correlation: Caron (1985) divided the upper Turonian to Coniacian sequences into the Marginotruncana sigali, Dicarinella primitiva and D. concavata zones in ascending order, while Sliter (1989) proposed the Marginotruncana sigali zone (KS22) and the D. concavata zone (KS23) (Fig. 4). Hardenbol et al. (1998) followed the definition of Sliter (1989), and established the M. schneegansi and $D$. concavata zones in this interval.

According to Robaszynski et al. (1979) and Caron (1985), characteristic species ranging from the late Turonian to Coniacian are Dicarinella primitiva, $D$. concavata, Marginotruncana paraconcavata, M. tarfayaensis and M. undulata. Among these species, D. concavata and M. paraconcavata occurred rarely in the uppermost part of M. pseudolinneiana zone in the Haboro-Kotanbetsu areas (Figs. 7 \& 8). Hence, this zone corresponds to the joint interval from the $M$. schneegansi zone to the lower part of the D. concavata zone (Fig. 4). The age of this zone is assigned to the late Turonian.

(11) Marginotruncana sinuosa Interval Zone

Definition: Biostratigraphic interval between the FAD of Marginotruncana sinuosa and the FAD of Contusotruncana fornicata.

Remarks: The double keel species are relatively abundant throughout this interval. The most abundant species among double-keeled forms is $M$. pseudolinneiana. Other representative species are D. canaliculata, D. imbricata, $M$. marginata and M. coronata (Figs. 7 \& 9). M. sinuosa is not common, but is consistently present throughout this interval (Figs. 7 \& 8). D. concavata are still rare or absent. The non-keeled forms, Whiteinella baltica, W. archaeocretacea and $W$. inornata are common in the lower part of this interval. Species of the genus Archaeoglobigerina (blowi, cretacea and bosquensis) first appeared, and their occurrences are common to abundant throughout this interval (Figs. $7 \& 8$ ). Other representative species are Globigerinelloides ultramicrus, Hedbergella 
delrioensis and Heterohelix reussi species that are few to common in abundance.

Age and Correlation: Dicarinella concavata is a marker species of the late Turonian to Santonian, the FAD of which is defined as the base of the $D$. concavata zone. This species disappears at the top of the following D. asymetrica zone, ranging from 90.65 to $83.5 \mathrm{Ma}$ in age (Fig. 4). The Turonian/Coniacian and Coniacian/Santonian boundaries are placed within the D. concavata zone, dated at $89 \mathrm{Ma}$ and $85.8 \mathrm{Ma}$, respectively (Fig. 4).

In the study area of Hokkkaido, the sporadic, rare occurrence of $D$. concavata causes difficulty in determining the FAD and LAD levels of this species. Instead, we used M. sinuosa as the boundary marker. This species occurred consistently throughout this interval, and its FAD is placed just below the Turonian/Coniacian boundary (Robaszynski et al., 1979; Caron, 1985; Lamolda and Proto-Decima, 1986; Kauffman et al., 1996). The M. sinuosa zone corresponds to the middle part of the $D$. concavata zone (Fig. 4). The age of this zone is assigned to the Coniacian to early Santonian.

(12) Contusotruncana fornicata Interval Zone

Definition: Biostratigraphic interval between the FAD of Contusotruncana fornicata and the FAD of Globotruncana arca.

Remarks: The non-keeled forms of archaeoglobigerinids (A. blowi, A. cretacea and A. bosquensis) are common to abundant throughout this interval (Figs. 7 \& 8). Specimens of M. pseudolinneiana are common to abundant, while those of Contusotruncana fornicata are few to rare. $H$. delrioensis, $H$. reussi and $G$. ultramicrus are still common (Figs. 7 \& 8).

Age and Correlation: In the tropical-subtropical regions, the D. asymetrica zone is defined as the total range zone of the nominate taxon, spanning from 84.9 to 83.5 Ma, the Santonian age (Fig. 4). However, D. asymetrica has not been as yet found from the investigated areas. In this paper, we used the FAD of $C$. fornicata as a boundary marker because this species first appears within the middle part of the $D$. concavata zone, very close to the Coniacian/Santonian boundary 
(Robaszynski et al., 1984; Caron, 1985; Lamolda et al., 1999). The C. fornicata zone is correlated with the joint interval from the upper part of the D. concavata zone to the lower part of the D. asymetrica zone (Fig. 4). The age of this zone is assigned to the middle Santonian.

(13) Globotruncana arca Interval Zone

Definition: The lower boundary of this zone is defined as the FAD of Globotruncana arca, but the upper boundary is unknown in the study area.

Remarks: The zonal markers of G. arca are rare, but are persistently present throughout this interval (Figs. 7 \& 8). The "real" Globotruncana of G. bulloides, G. lapparenti and G. linneiana first occurred within this interval, and were few in abundance (Fig. 9). The marginotruncanids ( $M$. pseudolinneiana and $M$. marginata) declined to a rare or absent status. Other representative, common species are the non-keeled forms (A. blowi, A. cretacea and A. bosquensis).

Age and Correlation: The foraminiferal criteria for the Santonian/Campanian boundary are the FAD of Globotruncana arca, the FAD of Globotrunanita elevata, and the LADs of D. concavata and D. asymetrica (e.g. Hancock and Gale, 1996). Hardenbol et al. (1998) used the latter three datums as the boundary markers, and placed the boundary at at 83.5Ma (Fig. 4).

The mudstones collected from the study area contain no specimens of $D$. asymetrica or G. elevata. Toshimitsu and Kikawa (1997) and Toshimitsu et al. (1998) suggested that the Santonian/Campanian boundary is placed between the LAD of M. pseudolinneiana and the FAD of G. arca in the Haboro section. According to Robaszynski et al. (1979) and Caron (1985), however, the stratigraphic ranges of these two species overlap because G. arca first appears within the D. asymetrica zone, and M. pseudolinneiana disappears at the top of this zone. This overlapping of the two species is also observed in the Haboro-gawa section (Fig. 8).

Recently, Moriya et al. (2001) reported a joint occurrence of the early Campanian assemblage consisting of G. arca, G. linneiana, C. fornicata and Rosita patelliformis from the Upper Haborogawa Formation in the Haboro area. 
Because R. patelliformis occurs in the Globotruncanita elevata zone (Robaszynski et al., 1984), the G. arca zone is correlated with the joint interval from upper part of the D. asymetrica zone to the lower part of the G. elevata zone (Fig. 4). Hence, the Santonian/Campanian boundary is placed within the G. arca zone (Figs. 8 \& 9). The age of this zone is assigned to the late Santonian to early Campanian.

\section{Bioprovincial implication based on planktonic foraminiferal assemblages}

\subsection{Bioprovince characteristics of Cretaceous planktonic foraminifera}

The distinct biogeographic provincialization of the planktonic foraminifers formed during the mid-Cretaceous when the rapid diversification of keeled-forms (rotaliporids, marginotruncanids, dicarinillids and globotruncanids) and non-keeled forms (globigerinellids, hedbergellids, ticinellids, whiteinellids and archaeoglobigerinids) occurred. Scheibnerova (1971) established four realms of Cretaceous foraminiferal bioprovinces: Tethyan (tropical-subtropical), Boreal in the Northern Hemisphere (cool temperature), Austral in the Southern Hemsphere (cool temperature) and Transition (warm temperate). In oceanic domains, Boreal is referred to areas polarward of the subtropical convergences (Malmgren, 1991).

The Tethyan assemblage consists of the highest diversity, single-keeled or double-keeled dominant assemblages, associated with common occurrences of non-keeled, biserial and planispiral groups. The Transitional Realm continues to be characterized by the Tethyan faunas, but their abundances decrease (Sliter, 1972; Malmgren, 1991). The Boreal assemblages are less diverse, compared to coeval Tethyan faunas, and include abundant non-keeled, globigerine-shape forms. Keeled species are sporadic, rare to absent, but sometimes increased sub-equal numbers with non-keeled species (Douglas and Rankin, 1969; Huber, 1992a; 1992b). The keeled- or weakly keeled-groups in the Boreal Province are represented by several species, often two to three in each zone; Praeglobotruncana stephani, P. delrioensis, Dicarinella algeriana, D. hagni (Albian-Turonian), Marginotruncana marinata, M. pseudolinneiana (Turonian-Santonian), Globotruncana arca, G. bulloides, and G. linneiana 
(Campanian-Maastrichtian)(Huber, 1992a). In the early and late Maastrichitian, the latitudinal differences were quite high, and endemic species were common among southern high-latitude assemblages, and keeled species were mostly restricted to the low to middle latitudes (Huber, 1992b).

\subsection{Assemblages of planktonic foraminifers from the Yezo Group}

The Aptian-Cenomanian planktonic foraminiferal assemblages in the Yezo Group include the Tethyan zonal markers with the exception of five species; namely, Globigerinelloides algerianus, Planomalina cheniourensis, P. buxtorfi, Rotalipora ticinensis and $R$. reicheli. However, species Rotalipora are generally rare to few, sometimes absent during the middle to late Cenomanian. The Turonian single-keeled Helvetoglobotruncana is constantly present in the study area, whereas other Turonian double-keeled markers (D. primitiva, M. schneegansi and M. sigali) are rare throughout the Turonian-Coniacian intervals (Fig. 9). The faunas of Coniacian-Santonian assemblages contain commonly double-keeled forms (Marginotruncana pseudolinneiana, Globotruncana linneiana G. bulloides and G. arca) that represent cosmopolitan distribution from the Tethyan to Transitional water masses (Sliter, 1972; Huber, 1992b; Malmgren, 1991), associated with rare or absent Tethyan Province markers (D. concavata, $D$. asymetrica and G. elevata).

Non-keeled/keeled planktonic foraminiferal ratios are also used as an environmental indicator of Tethyan and Boreal bioprovinces (Gasinski, 1997). The non-keeled forms increase in the assemblages of the Boreal (Austral) realm. Globigerinelloides and heterohelicids are also abundant in the Boreal bioprovince (Huber, 1992a; 1992b). The assemblages of the Yezo Group consist consistently of single- or double-keeled species (Fig. 9), whereas non-keeled groups such as Whiteinella and Archaeoglobigerina are, as a whole, abundant in many samples through the late Cenomanian to Turonian (Figs. 5 \& 7). The keeled-species Marginotruncana and Dicarinella occasionally increased after the Coniacian, especially in the Santonian interval.

Assemblage characteristics suggest that the bioprovince of the Cretaceous Hokkaido tends to belong to the Transitional realm, the intermediate between the Tethyan and Boreal realms. Tethyan species 
frequently migrated into the area where the Yezo Group had been deposited during the middle Albian to early Turonian (T. primula to H. helvetica zones). Assemblages younger than the late Turonian interval lack the Tethyan zonal markers. Instead, the cosmopolitan faunas of double-keeled forms (e.g. Marginotruncana pseudolinneiana) and non-keeled forms (whiteinellids and archaeoglobigerinids) are dominant throughout the sequence. The rapid change of faunal composition observed in Central Hokkaido implies that a global cooling occurred in the late Turonian. However, the abundant occurrence of double-keeled species throughout the Coniacian-Santonian intervals indicates that the bioprovince of Central Hokkaido was located in the Transitional Realm.

\section{Acknowledgements}

This study was partly supported by funds of the Grant-in-Aid for Scientific Research No. 12640457 and No. 13354006 from the Ministry of Education, Culture, Sports, Science and Technology. We are grateful to R. Mark Leckie and an anonymous reviewer for helpful suggestions and critical reading of the manuscript. We also acknowledge Hiromichi Hirano and Claudia C. Johnson for inviting us to participate in the volume.

\section{References}

Ando, H., 1990a. Stratigraphy and shallow marine sedimentary facies of the Mikasa Formation, Middle Yezo Group (Upper Cretaceous). The Journal of the Geological Society of Japan, 96, 279-295 (in Japanese with English Abstract).

Ando, H., 1990b. Shallow-marine sedimentary facies distribution and progradational sequences of the Mikasa Formation, Middle Yezo Group (Upper Cretaceous). The Journal of the Geological Society of Japan, 96, 453-469 (in Japanese with English Abstract).

Arthur, M.A., Schlanger, S.O., Jenkins, H.C., 1987. The Cenomanian-Turonian Oceanic Anoxic Event, II. Palaeoceanographic controls on organic-matter production and preservation. In: Brooks, J., Fleet, A.J.(Eds.), Marine 
Petroleum Source Rocks. Geological Society Special Publication, No. 26, pp. 401-420.

Barron, E.J., Harrison, C.G., Sloan II, J.L, Hay, W.W., 1981. Paleogeography, 180 million years ago to the present. Eclogae geologicae Helvetiae, 74, 443-470.

Barron, E.J., 1983. A warm, equable Cretaceous: The nature of the problem. Earth-Science Reviews, 29, 305-338.

Berner, R.A., 1994. Geocard II: A revised model of atomospheric $\mathrm{CO}_{2}$ over Phanerozoic time. American Journal of Science, 294, 56-91.

Caron, M., 1985. Cretaceous planktic foraminifera. In: Bolli, H.M., Saunders, J.B., Perch-Nielsen, K. (Eds.), Plankton stratigraphy, Cambridge University Press, Cambridge, pp. 17-86.

Clarke, L. J, Jenkins, H. C., 1999. New oxygen isotope evidence for long-term Cretaceous climatic change in the Southern Hemisphere. Geology, 27, 699-702.

Douglas, R.G., 1969. Upper Cretaceous planktonic foraminifera in northern California Part 1 -Systematics. Micropaleontology, 15, 151-209.

Douglas, R.G., Rankin, C., 1969. Cretaceous planktonic foraminifera from Bornholm and their zoogeographic significance. Lethaia, 2, 185-217.

Erbacher, J., Thurow, J., Littke, R., 1996. Evolution patterns of radiolaria and organic matter variations: A new approach to identify sea-level changes in mid-Cretaceous pelagic environments. Geology, 24, 499-502.

Erbacher, J., Thurow, J., 1997. Influence of oceanic anoxic events on the evolution of mid-Cretaceous radiolaria in the North Atlantic and western Tethys. Marine Micropaleontology, 30, 139-158.

Frakes, L.A., 1979. In: Climates throughout geologic times. Elsevier, Amsterdam, 310 pp.

Gasinski, M.A., 1997. Tethyan-Boreal connection: influence on the evolution of mid-Cretaceous planktonic foraminiferids. Cretaceous Research, 18, 505-514.

Gradstein, F.M., Agterberg, F.P., Ogg, J.G., Hardenbol, J., Veen, P.V., Huang, Z., 1995. A Triassic, Jurassic and Cretaceous time scale. SEPM Special Publication, No. 54, 95-126.

Hancock, J. M., Gale, A. S., 1996. The Campanian Stage. Bulletin de'l Institut 
Royal des Sciences Naturelles de Belgique, Sciences de la Terre 66-Supplement, 103-109.

Hardenbol, J., Thierry, J., Farley, M.B., Jacquin, T., de Graciansky, P.-C., Vail, P.R., 1998. Mesozoic and Cenozoic sequence chronostratigraphic framework of European basins. SEPM Special Publication, No. 60, 3-13.

Hart, M.B., Bailey, H.W., Crittenden, S., Fletcher, B.N., Price, R.J., Swiecicki, A., 1989. Cretaceous. In: Jenkins, D.G., Murray, J.W. (Eds.), Stratigraphical atlas of fossil foraminifera, Second Edition. John Wiley and Sons, Southampton, pp. 273-365.

Hasegawa, T., Saito, T., 1993. Global synchroneity of a positive carbon isotope excursion at the Cenomanian/Turonian boundary: Validation by calcareous microfossil biostratigraphy of the Yezo Group, Hokkaido, Japan. The Island Arc, 3, 181-191.

Hasegawa, T., 1995. Correlation of the Cenomanian/Turonian boundary between Japan and Western Interior of the United States. The Journal of the Geological Society of Japan, 101, 2-12.

Hasegawa, T., 1999. Planktonic foraminifera and biochronology of the Cenomanian-Turonian (Cretaceous) sequence in the Oyubari area, Hokkaido, Japan. Paleontological Research, 3, 173-192.

Hasegawa, T., Hatsugai, T., 2000. Carbon-isotope stratigraphy and its chronostratigraphic significance for the Cretaceous Yezo Group, Kotanbetsu area, Hokkaido, Japan. Paleontological Research, 4, 95-106.

Herman, A.B., Spicer, R.A., 1996. Palaeobotanical evidence for a warm Cretaceous Arctic Ocean. Nature, 380, 330-333.

Hirano, H., Tanabe, K., Ando, H., Futakami, M., 1992. Cretaceous forearc basin of Central Hokkaido: Lithofacies and biofacies characteristics. In: Adachi, M., Suzuki, K. (Eds.), 29th IGC field trip guidebook, Nagoya University, Nagoya, pp. 45-80.

Huber, B.T., 1992a. Upper Cretaceous planktic foraminiferal biozonation for the Austral Realm. Marine Micropaleontology, 20, 107-128.

Huber, B.T., 1992b. Paleobiogeography of Campanian-Maastrichtian foraminifera in the southern high latitudes. Palaeogeography, Palaeoclimatology, Palaeoecology, 92, 325-360. 
Huber, B.T., Hodell, D.A., Hamilton, C.P., 1995. Middle-Late Cretaceous climate of the southern high latitudes: Stable isotope evidence for minimal equator-pole thermal gradients. GSA Bulletin, 107, 1164-1191.

Jenkyns, H.C., Gale, A.S., Corfield, R.M., 1994. Carbon-and oxygen-isotope stratigraphy of the English Chalk and Italian Scaglia and its palaeoclimatic significance. Geological Magazine, 131, 1-34.

Johnson, C.C., Barron, E.J., Kauffman, E.G., Arthur, M.A., Fawcett, P.J. and Yasuda, M.K., 1996. Middle Cretaceous reef collapse linked to ocean heat transport. Geology, 24, 376-380.

Kaiho, K., Fujiwara, O. and Motoyama, I., 1993. Mid-Cretaceous faunal turnover of intermediate-water benthic foraminifera in northwestern Pacific Ocean margin. Marine Micropaleontology, 23, 13-49.

Kauffman, E.G., Kennedy, W.J. and Wood, C.J., 1996. The Coniacian stage boundaries. Bulletin de l'Institut Royal des Sciences Naturelles de Belgique, Sciences de la Terre 66-Supplement, 81-94.

Kiminami, K., Niida, K., Ando, A., Kito, N., Iwata, I., Miyashita, S., Tajika, J., and Sakakibara M., 1992. Cretaceous-Paleogene arc-trench systems in Hokkaido. In: Adachi, M., Suzuki, K. (Eds.), 29th IGC field trip guidebook. Nagoya University, Nagoya, pp. 1-43.

Lamolda, M.A., Proto-Decima, F., 1986. The Turonian-Coniacian boundary in Ollogoyen (Basque Country); Foraminifers and nannoplankton. Cretaceous Research, 7, 63-75.

Lamolda, M.A., Melinte, M.C., Peryt, yD., 1999. Datos micropaleontológicos preliminares Sobre el Límite Coniaciense-Santoniense en Olazagutia (Navarra, España). Revista Espanola de Micropaleontologia, 31, 337-345.

Leckie, R.M., 1984. Mid-Cretaceous planktonic foraminiferal biostratigraphy off Central Morocco, Deep Sea Drilling Project Leg 79, Sites 545 and 547. In: Hintz, K., Winterer, E. L. et. al. (Eds.), Initial Reports of the Deep Sea Drilling Project. Washington (U.S. Government Printing Office, pp. 579-620,

Longoria, J.F., 1974. Stratigraphic, morphologic and taxonomic studies of Aptian planktonic foraminifera. Revista Espanola de Micropaleontologia, numero. extraord, 1-107. 
MacLeod, K.G., Huber, B.T., Ducharme, M.l., 2000. Paleontological and geochemical constraints on the deep ocean during the Cretaceous greenhouse interval. In: Huber, B.H., MacLeod, K.G., Wing, S.L. (Eds.), Warm Climates in Earth History. Cambridge University Press, Cambridge, 241-274.

Maiya, S., Takayanagi, Y., 1977. Cretaceous foraminiferal biostratigraphy of Hokkaido. Palaeontological Society of Japan, Special Papers, No. 21, 41-51. Maiya, S., 1985. Cretaceous foraminiferal zonations of Japan and their international correlation. The Memoirs of the Geological Society of Japan, No. 26, $89-99$ (in Japanese with English Abstract).

Malmgren, B.A., 1991. Biogeographic patterns in terminal Cretaceous planktonic foraminiferal from Tethyan and warm Transitional waters. Marine Micropaleontology, 18, 73-99.

Moriya, K., Nishi, H., Tanabe, K., 2001. Age calibration of megafossil biochronology based on Early Campanian planktonic foraminifera from Hokkaido, Japan. Paleontological Research, 5, 277-282.

Motoyama, I., Fujiwara, O., Kaiho, K., Murota, T., 1991. Lithostratigraphy and calcareous microfossil biochronology of the Cretaceous strata in the Oyubari area, Hokkaido, Japan. The Journal of the Geological Society of Japan, 97, 507-527 (in Japanese with English Abstract).

Parrish, J.T., Daniel, I.L., Kennedy, E.M., Spicer, R.A., 1998. Paleoclimatic significance of Mid-Cretaceous floras from the Middle Clarence Valley, New Zealand. Palaios, 13, 149-159.

Robaszynski, F., Caron, M., European Working Group on Planktonic foraminifera, 1979. Atlas de Foraminiferes planctoniques du Cretace moyen, Parts 1-2. Cahiers de micropaleontologie, 1 and 2, 1-185 and 1-181.

Robaszynski, F., Caron, M., Donoso, J.M.G., Wonders, A.A.H., European Working Group on Planktonic foraminifera, 1984. Atlas of Late Cretaceous Globotruncanids. Revue de Micropaleontologie, 26, 145-305.

Robaszynski, F., Caron, M., 1995. Foraminiféres planctoniques du Crétacé: commentaire de la zonation Europe-Méditerranée. Bull. Soc. géol. Fraqnce, t. $166, n^{\circ} 6,681-692$.

Scheibnerova, V., 1971. Foraminifera and the Mesozoic biogeoprovinces. Geol. 
Sur. N.S.W., 13, 135-174.

Scholle, P.A., Arthur, M.A., 1980. Carbon isotope fluctuations in Cretaceous pelagic limestones: Potential stratigraphy and petroleum exploration tool. The American Association of Petroleum Geologists Bulletin, 64, 67-87.

Sliter, W.V., 1972. Upper Cretaceous planktonic foraminiferal zoogeography and ecology -eastern Pacific margin. Palaeogeography, Palaeoclimatology, Palaeoecology, 12, 15-31.

Sliter, W.V., 1989. Biostratigraphic zonation for Cretaceous planktonic foraminifers examined in thin section. Journal of Foraminiferal Research, 19, 1-19.

Spicer, R.A., Parrish, J.T., 1986. Paleobotanical evidence for cool north polar climates in middle Cretaceous (Albian-Cenomanian) time. Geology, 14, 703-706.

Takashima, R., Nishi, H., Saito, T., Hasegawa, T., 1997. Geology and planktonic foraminiferal biostratigraphy of Cretaceous strata distributed along the Shuparo River, Hokkaido, Japan. The Journal of the Geological Society of Japan, 103, 543-563 (in Japanese with English Abstract).

Takayanagi, Y., 1965. Upper Cretaceous planktonic foraminifera from the Putah Creek subsurface section along the Yolo-Solano County Line, California. Science Report of the Tohoku University, Second Series (Geology), 36, 161-237.

Tarduno, J.A., Brinkman, D.B., Renne, P.R., Cottrell, R.D., Scher, H., Castillo, P., 1998. Evidence for extreme Climatic warmth from Late Cretaceous arctic vertebrates. Science, 282, 2241-2244.

Toshimitsu, S., 1988. Biostratigraphy of the Upper Cretaceous Santonian Stage in Northwestern Hokkaido. The Memories of the Faculty of Science, Kyushu University, Series D, Geology, Vol. XXVI, No. 2, 125-192.

Toshimitsu, S., Kikawa, E., 1997. Bio- and magnetostratigraphy of the Santonian-Campanian transition in northwestern Hokkaido, Japan. Momories of the Geological Society of Japan, No. 48, 142-151.

Toshimitsu, S., Maiya, S., Inoue, Y., Takahashi, T., 1998. Integrated megafossil-foraminiferal biostratigraphy of the Santonian to lower Campanian (Upper Cretaceous) succession in northwestern Hokkaido, 
Japan. Cretaceous Research, 19, 69-85.

Wani, R., Hirano, H., 2000. Upper Cretaceous biostratigraphy in the Kotanbetsu area, northwestern Hokkaido. The Journal of the Geological Society of Japan, 106, 171-188 (in Japanese with English Abstract). 


\section{Caption}

Figure 1. Paleogeographic reconstuction for the middle Cretaceous (about 80 Ma)(Barron et al., 1981), including Cretaceous ocean site locations (numbers) and land sections (alphabets). Hokkaido was located at about $40-50^{\circ} \mathrm{N}$. The symbols of locations are: Tu; Tunisia, Is; Israel, Eng; England, Bo; Bornholm near Denmark, Po; Poland, Cau; Caucasus, JP; Japan, Ca; California.

Figure 2. Locations of the investigated sections for biostratigraphic studies in the Yubari and Haboro-Kotanbrtsu areas.

Figure 3. Summary of the litho- and biostratigraphy in the three representative sections (Shuparogawa section in the Oyubari area, Kotanbetsu-gawa section in the Kotanbetsu area, and Nakanofutamatazawa section in the Haboro area). The zones of planktonic foraminifers defined in this paper are referred in Figure 4. The lithostratigraphy in the Oyubari section is based on Motoyama et al. (1991) and Takashima et al. (1997), while that in the Kotanbetsu and Haboro areas is based on Wani and Hirano (2000) and Toshimitsu (1988).

Figure 4. Correlation between a zonal scheme proposed in this paper and the important standard zonations of the Tethyan Realm. Time scales of Gradstein et al. (1995) and Hardenbol et al. (1998) are adopted.

Figure 5. Biostratigraphic summary and distribution of selected planktonic foraminifers in the Yezo Group exposed along three sections of Shuparo-gawa, Tenguno-sawa and Hachijuhappan-sawa in the northern part of the Oyubari area. Locations are shown in Fig. 2. The stratigraphic range of this section spans from upper Aptian to Turonian.

Figure 6. Biostratigraphic summary and distribution of selected planktonic foraminifera of the Kanajiri-zawa section in the Kotanbetsu area. Its 
locations are shown in Fig. 2. The strata exposed in this section range from Albian to lowest Turonian.

Figure 7. Biostratigraphic summary and distribution of selected planktonic foraminifera of the Kotanbetsu-gawa section in the Haboro-Kotanbetu area, located in the northern part of Central Hokkaido (Fig. 2). The stratigrapgic range of the sequence spans from Cenomanian to Santonian.

Figure 8. Biostratigraphic summary and distribution of selected planktonic foraminifers in the Nakanofutamata-gawa section in the Haboro area. This section is located in the northernmost part of the investigated area. The foraminiferal assemblages are assigned to the Turonian to Campanian.

Figure 8. Stratigraphic distribution of the representative planktonic foraminifers and geological ages in the three sections for study.

Explanation of Plates

\section{PLATE I}

Albian to Cenomanian zonal markers in the Cretaceous Yezo Group. Locations of the study sections are shown in Fig. 2. a: spiral view, b: edge view, c: umbilical view, except Biticinella breggiensis.

1. Ticinella primula Luterbacher, Sample SP001 from the Shuparo-gawa section. 2. Biticinella breggiensis (Gandolfi), Sample SP001 from the Shuparo-gawa section. a and c: lateral view, b: apertural face. 3. Ticinella subticiensis (Gandolfi), Sample KTS-143 from the Kanajiri-zawa section. 4. Rotalipora appenninica (Renz), Sample TG040 from the Tenguno-sawa section. 5. Praeglobotruncana stephani (Gandolfi), Sample KOT 505 from the Kotanbetsu-gawa section. 6. Rotalipora globotruncanoides Sigal, Sample TG 025 from Tenguno-sawa section. 7. Rotalipora greenhornensis (Morrow), Sample KTJ-129 from the Kanajiri-zawa section. 8. Rotalipora cushmani (Morrow), Sample KJS-136 from the Kanajiri-zawa section. 9. Praeglobotruncana gibba Klaus, Sample KOT 505 from the Kotanbetsu-gawa section.

PLATE II 
Turonian to Campanian zonal markers in the Cretaceous Yezo Group. Locations of the study sections are shown in Fig. 2.

10. Whiteinella archaeocretacea Pessagno, Sample OBR 202 from the Obirashibe-gawa section. 11. Helvetoglotruncana helvetica (Bolli), KOT 113 from the Kotanbetsu-gawa section. 12. Marginotruncana sinuosa Porthault, Sample KOT 603 from the Kotanbetsu-gawa section. 13. Archaeoglobigerina blowi Pessagno, Sample SK-114 from the Sakasa-gawa section. 14. Archaeoglobigerina cretacea (d'Orbigny), Sample SK-116 from the Sakasa-gawa section. 15. Dicarinella concavata (Brotzen), Sample KOT-605 from the Kotanbetsu-gawa section. 16. Contusotruncana fornicata (Plummer), Sample SK-115 from the Sakasa-gawa section. 17. Globotruncana arca (Cushman), Sample SK-124 from the Sakasa-gawa section. 


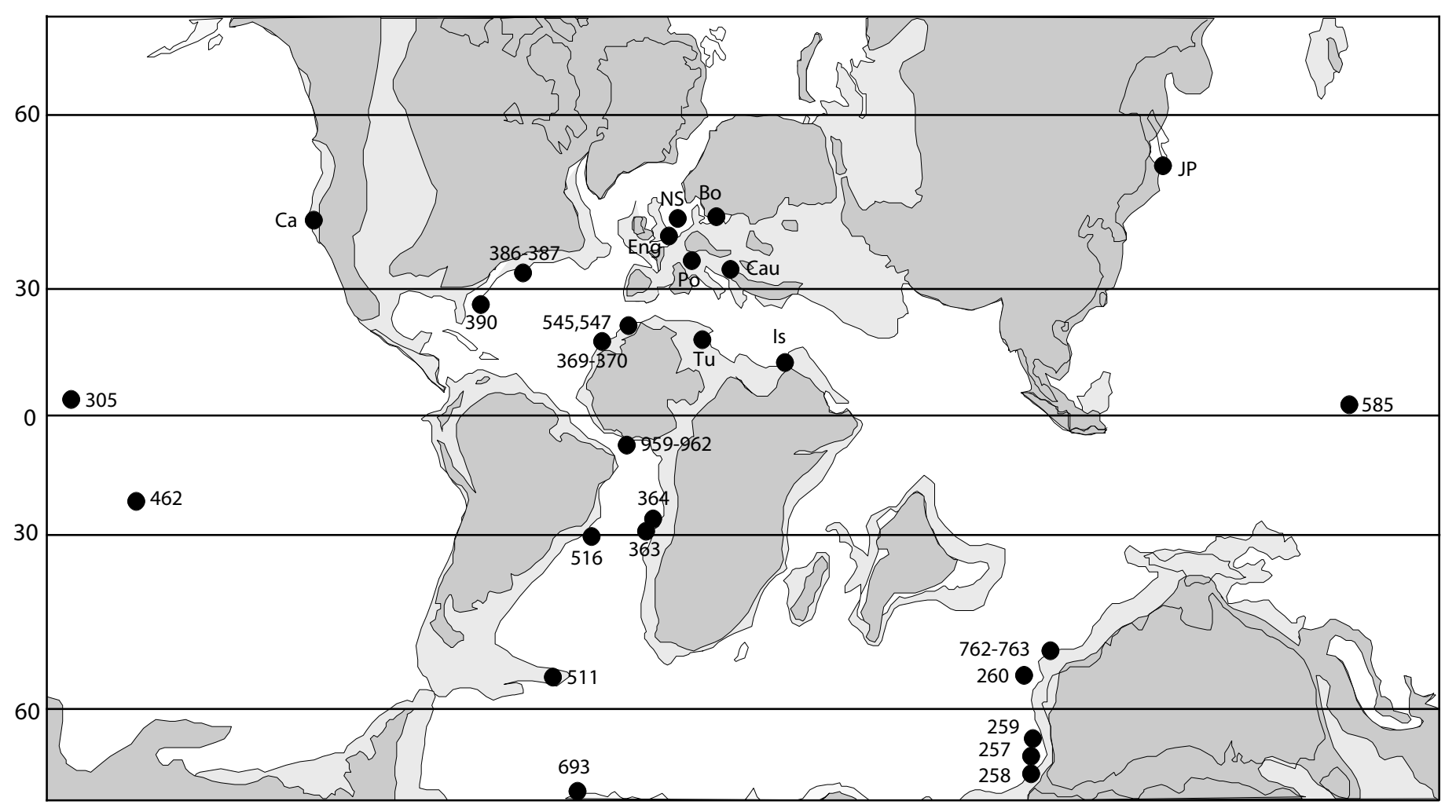

Nishi et al. Figure 1 


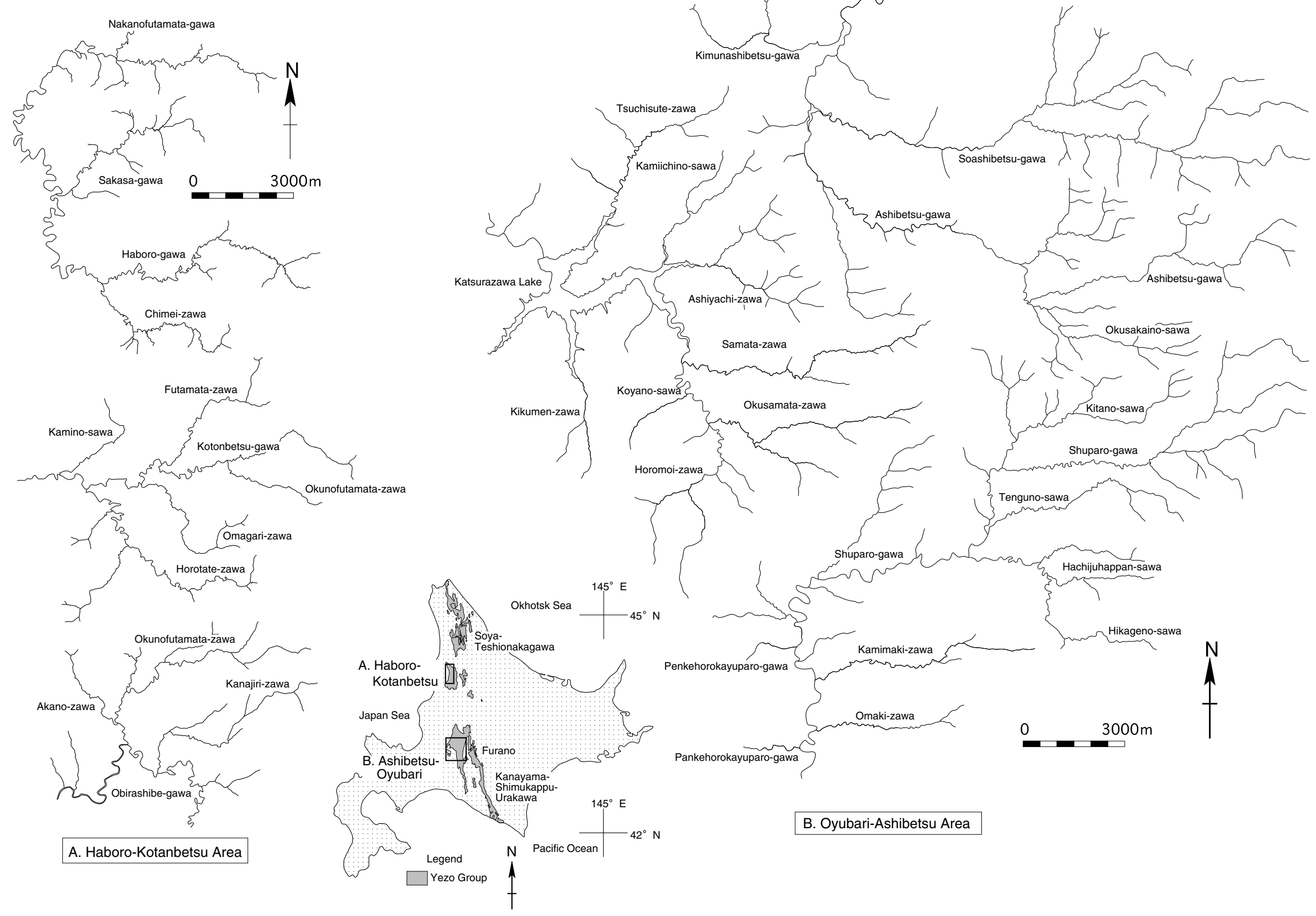

Nishi et al., Figure 2 


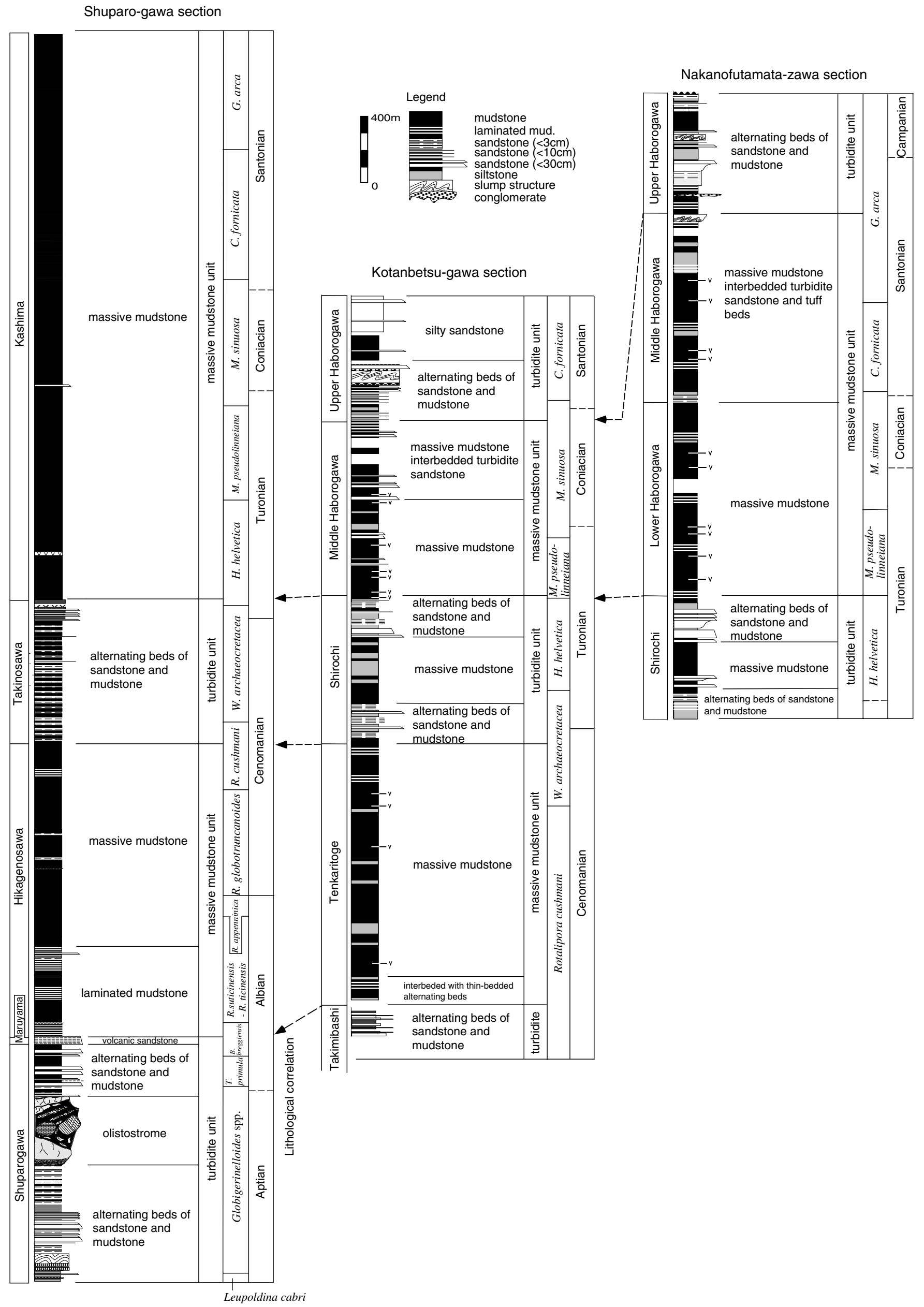




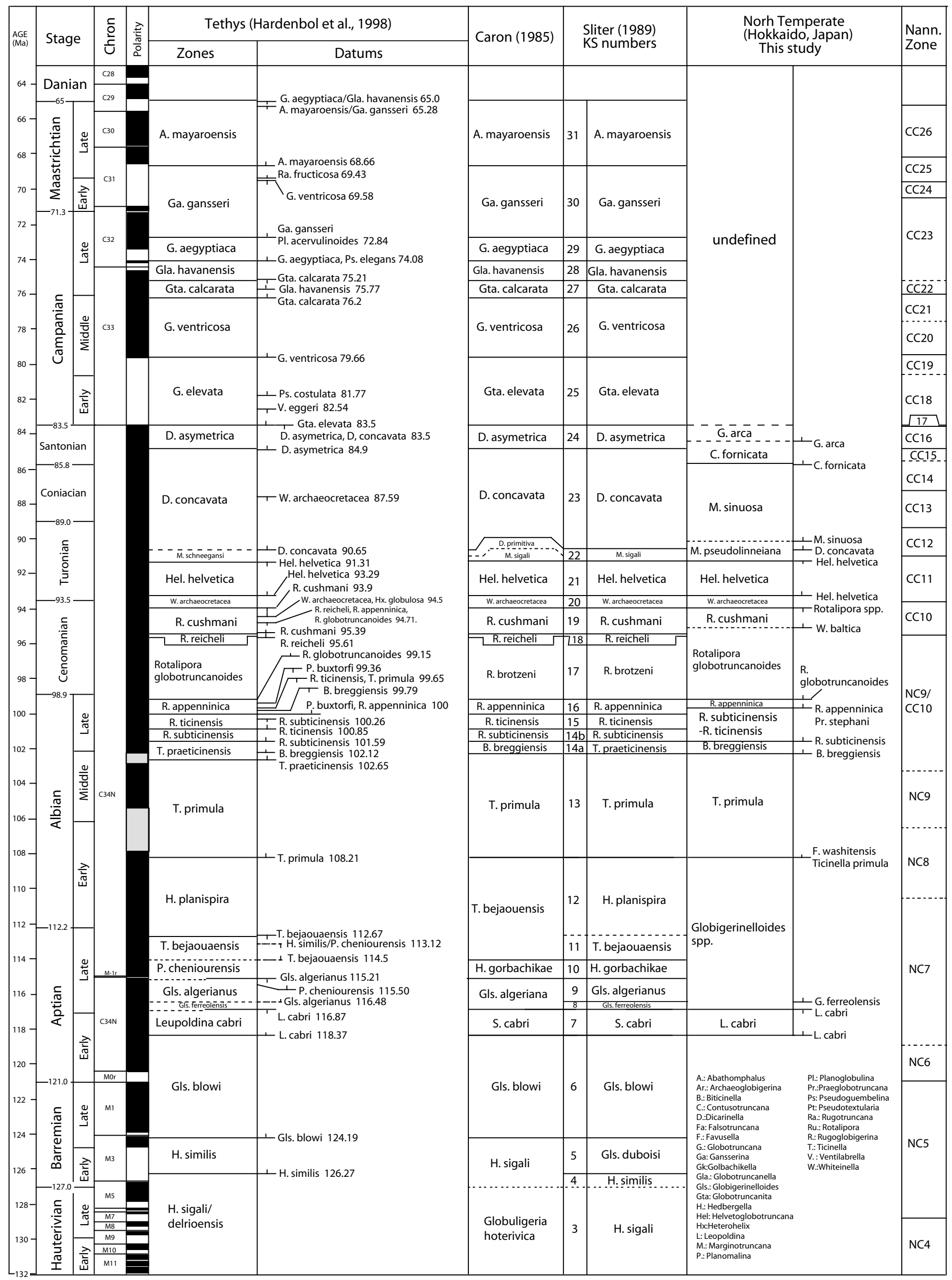




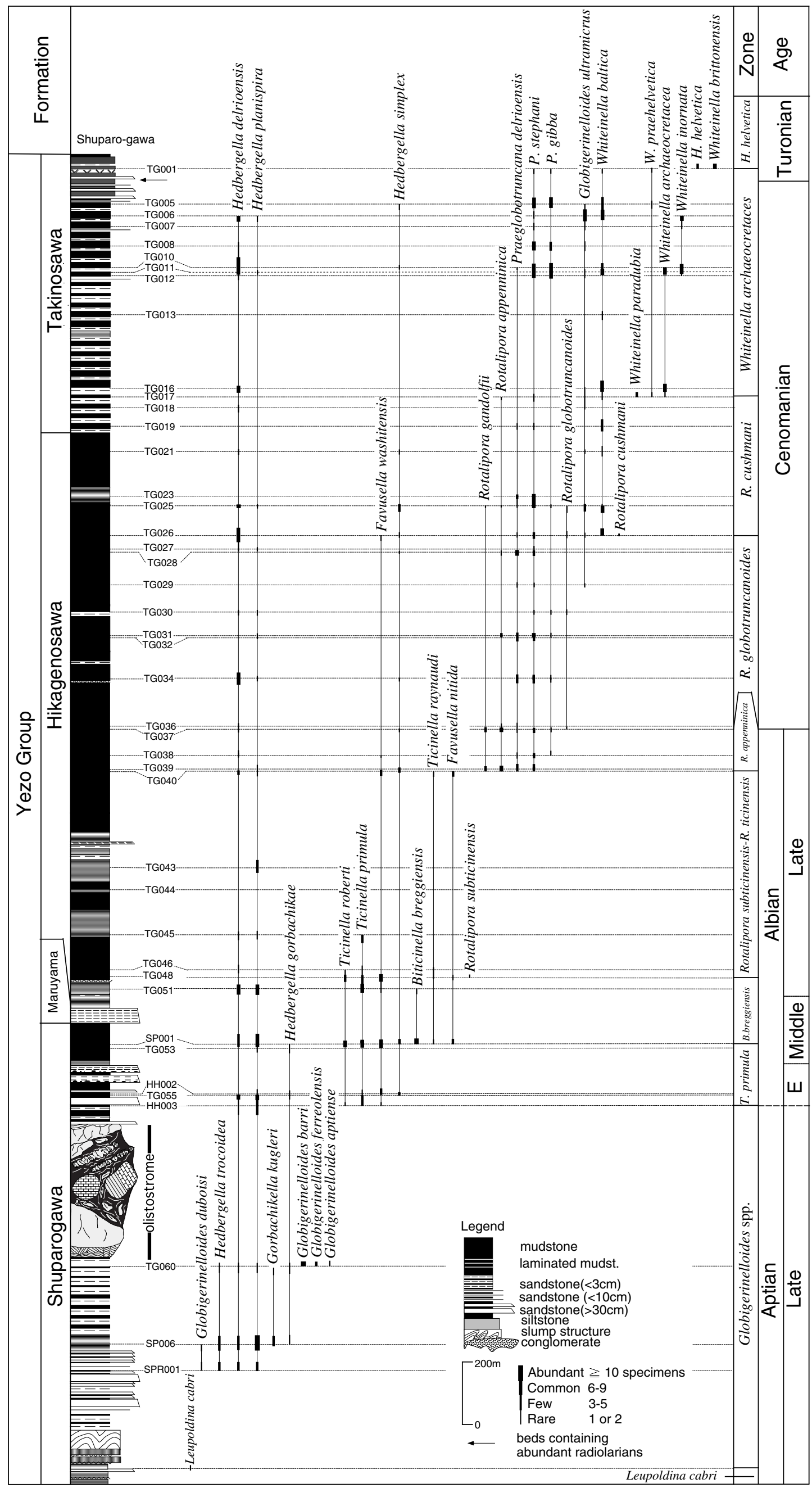




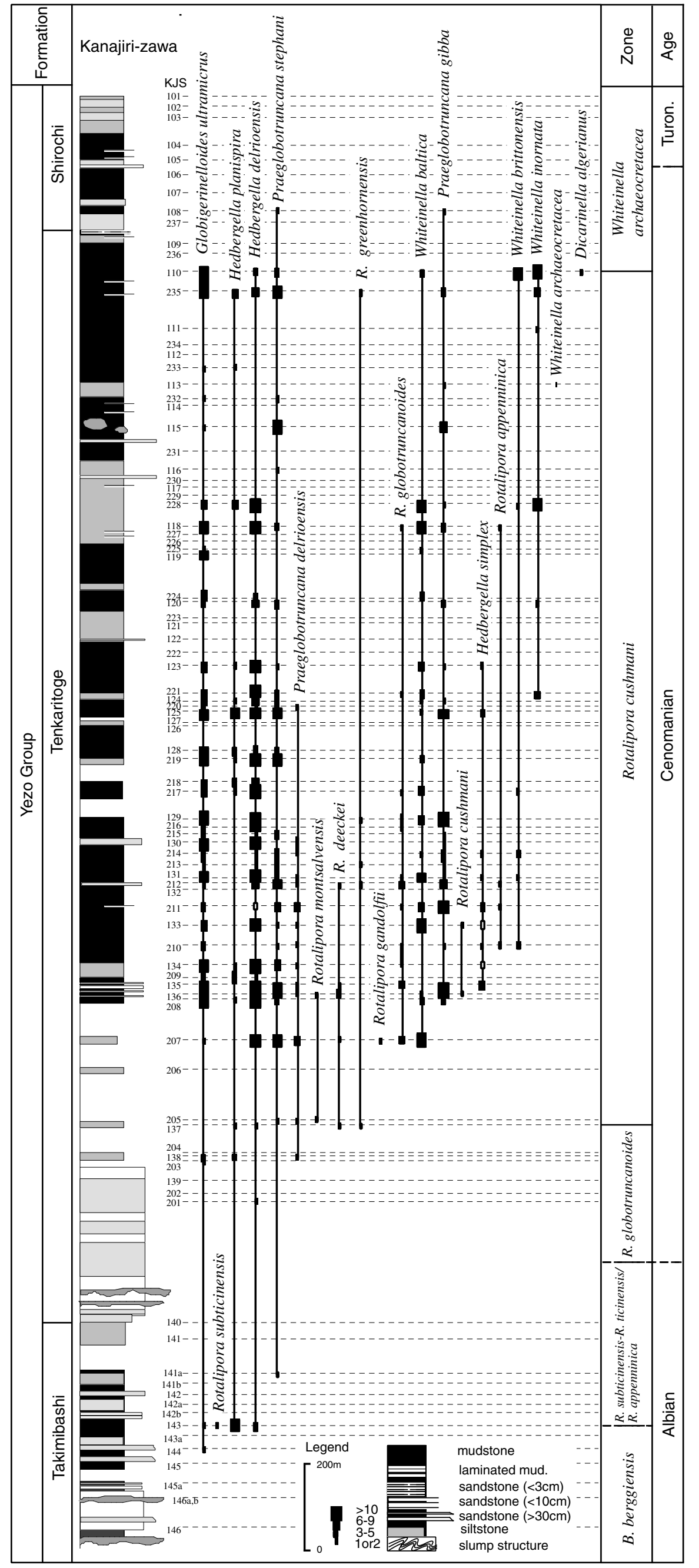

Nishi et al., Figure 6 


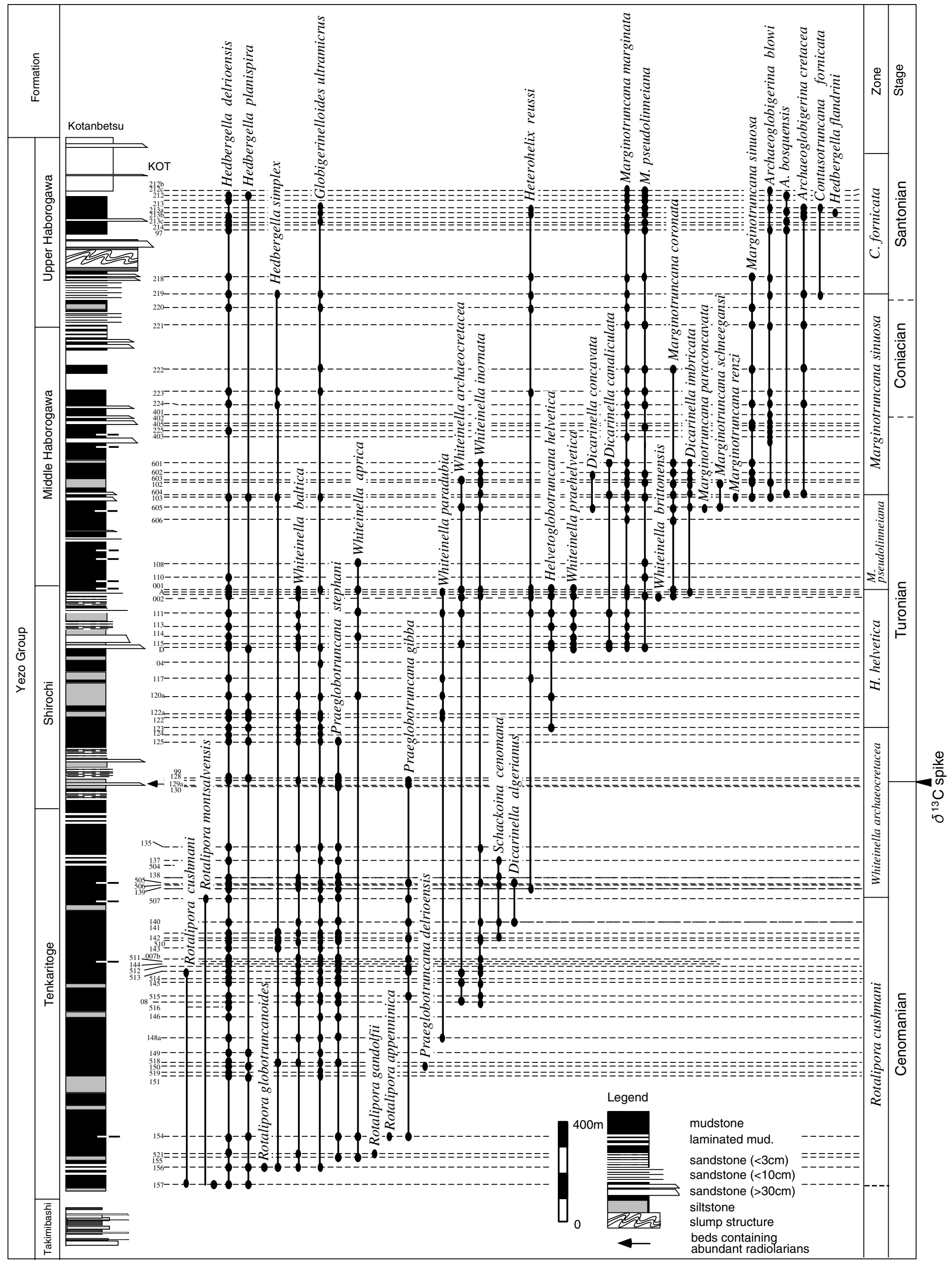

Nishi et al., Figure 7 




Nishi et al., Figure 8 
Nishi et al., Figure 9

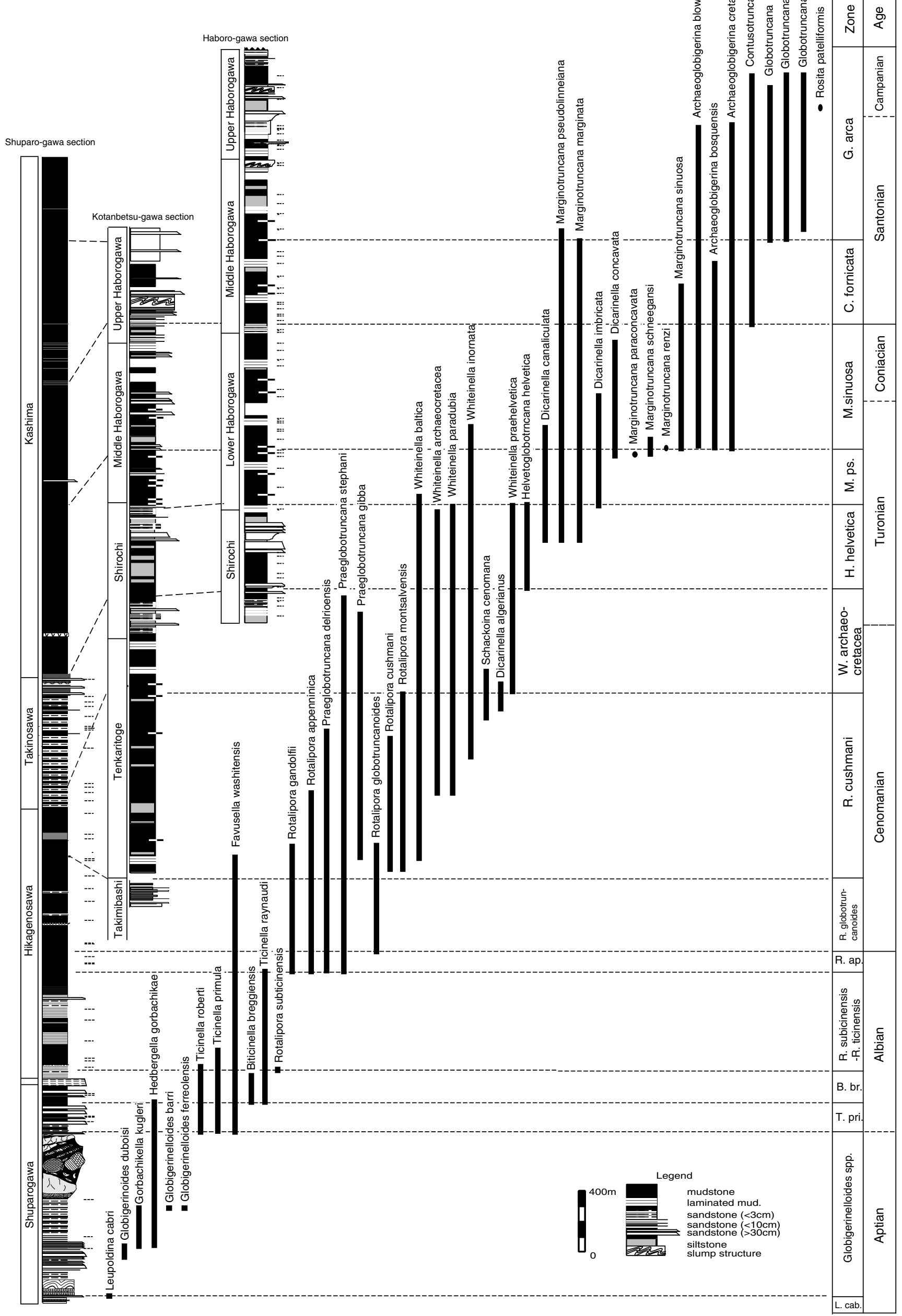




\section{PLA TE 1}
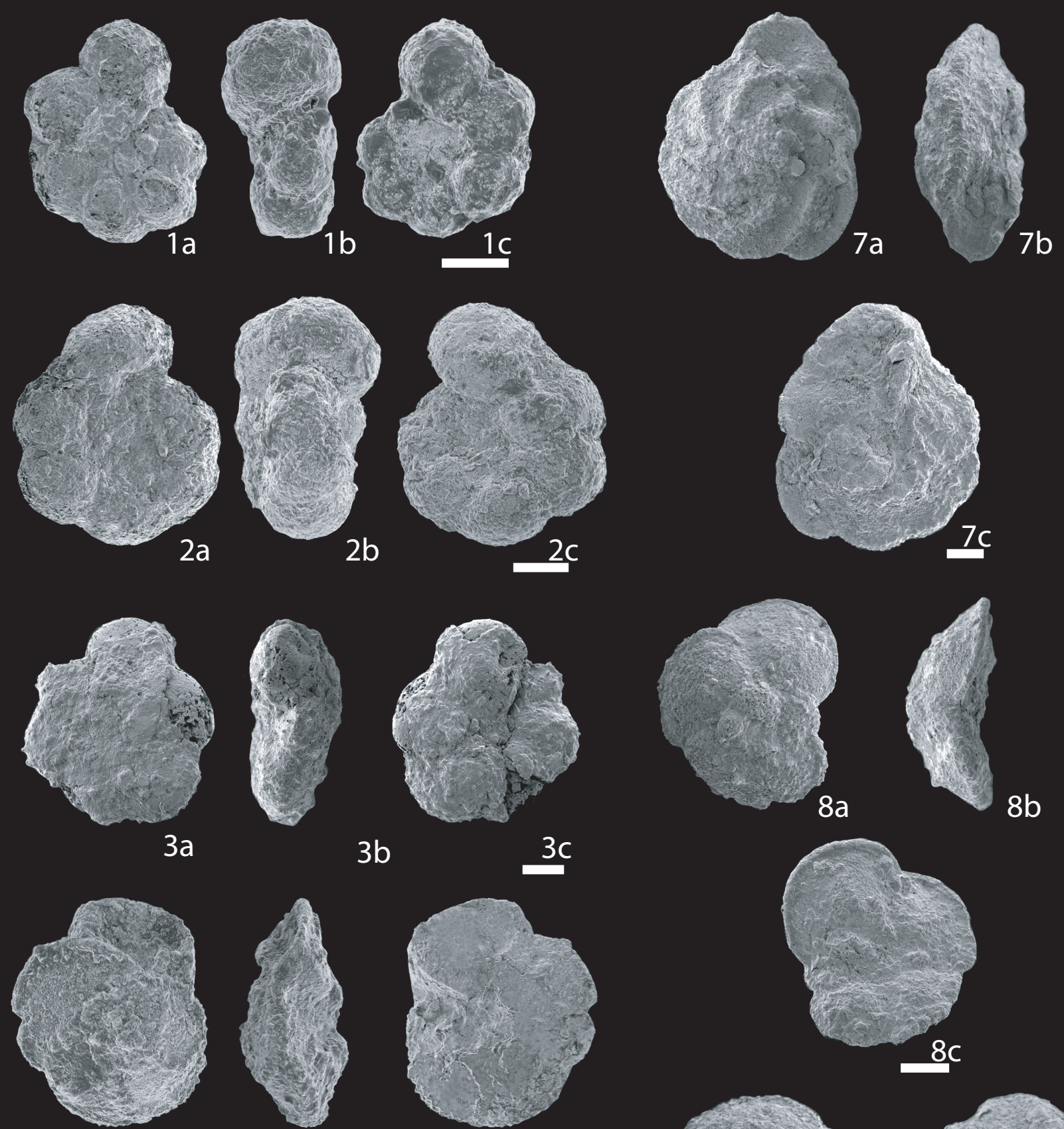

$3 b$
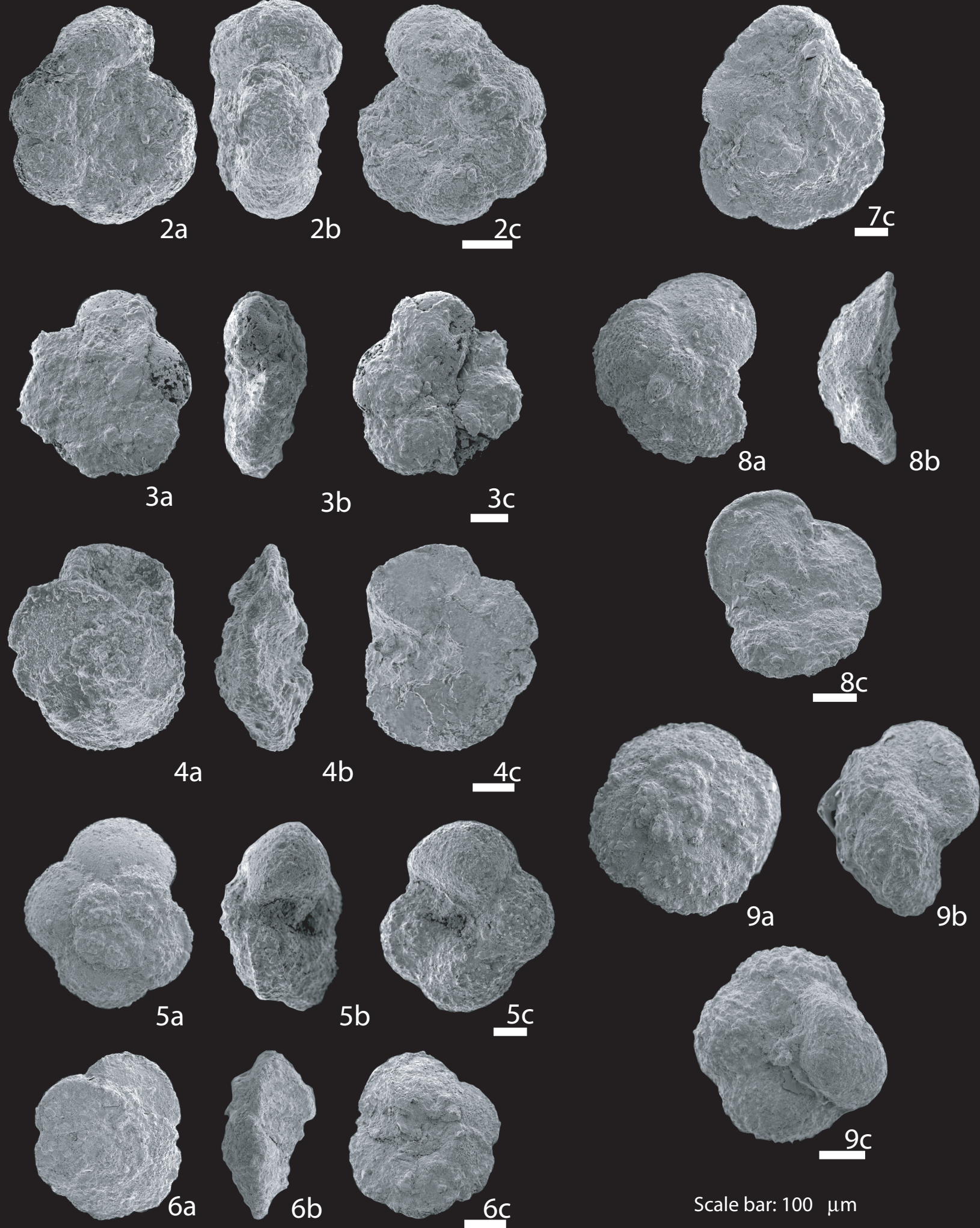

Scale bar: $100 \mu \mathrm{m}$ 
Nishi et al., PLATE 2

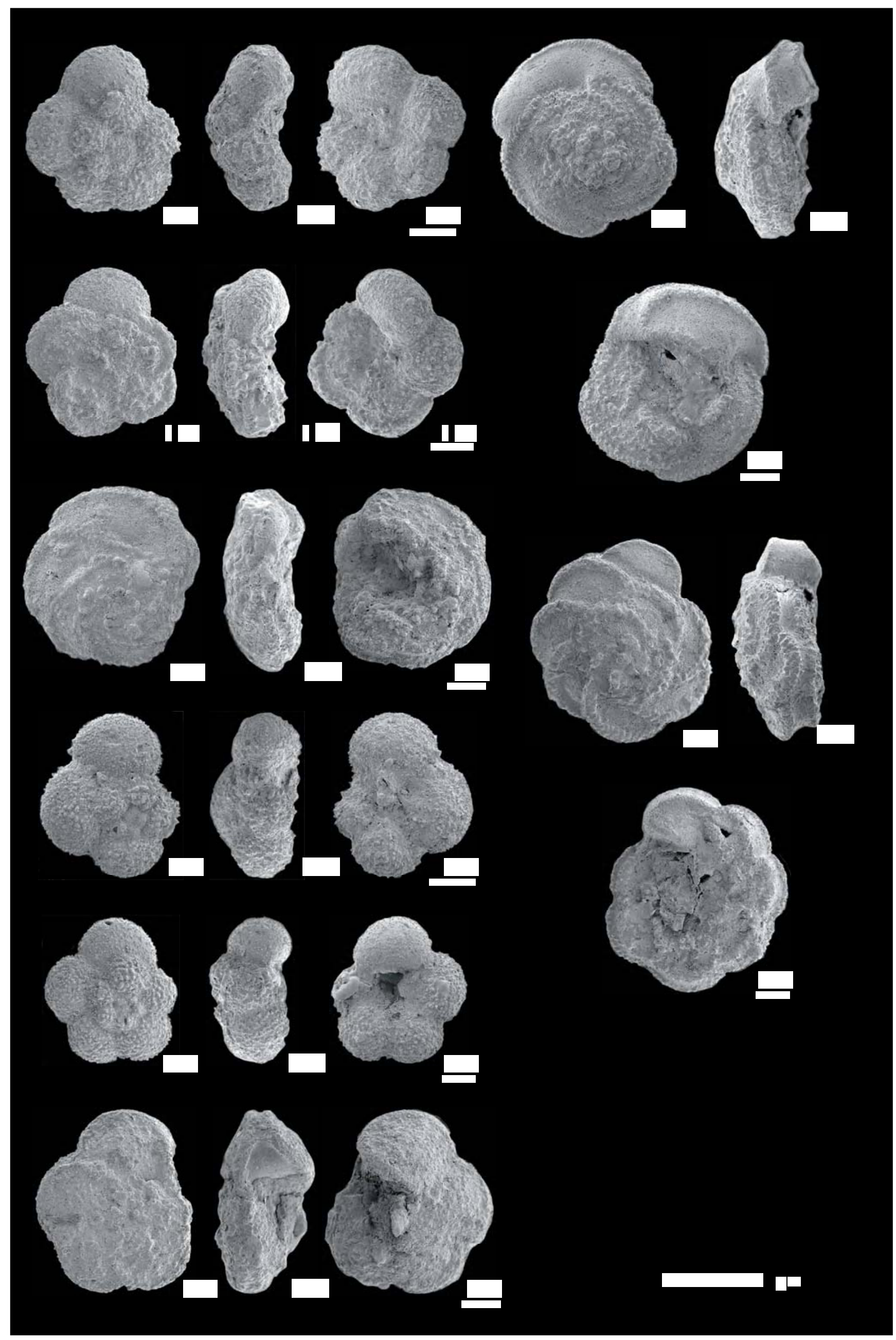

